\title{
Dietary fibre and blood pressure
}

\author{
ANGELA WRIGHT, P G BURSTYN, M J GIBNEY
}

British Medical fournal, 1979, 2, 1541-1543

\section{Summary and conclusions}

Ninety-four volunteers participated in a three-day weighed dietary survey and had their blood pressures measured once. They were classified according to their fibre intake. Subjects with a high-fibre intake were found to have lower mean blood pressures than those with a low-fibre intake. Forty-two of the volunteers further participated in a group of experiments. Those eating a high-fibre diet decreased their dietary fibre, and those eating a low-fibre diet increased their dietary fibre. The first group (11 subjects) showed increased mean blood pressures after four weeks of eating the experimental diet. The last group (31 subjects) showed decreased mean blood pressures after four weeks of eating the experimental diet. The 11 subjects consuming the low-fibre experimental diet showed a decrease in mean blood pressure when some of the saturated fat in their diet was replaced by polyunsaturated fat. A similar substitution carried out by 14 of the subjects consuming the high-fibre experimental diet also resulted in decreased mean blood pressure, but this was not statistically significant. Twelve more volunteers, with hypertension, were all found to have low-fibre diets. They consumed a high-fibre diet for a six-week experimental period, but their mean blood pressures did not decrease significantly; individual recordings varied substantially during this period.

It is suggested that differences in the type and quantity of dietary fibre and fat may be responsible for the lower mean blood pressures of groups of vegetarians compared with similar groups of non-vegetarians.

\section{Introduction}

Lack of fibre in the western European diet has been blamed for causing or accelerating many gastrointestinal, metabolic, and cardiovascular diseases. ${ }^{12}$ Although cardiovascular diseases have been linked to excessive dietary intake of cholesterol and saturated fats, ${ }^{3}$ there is considerable dissent on this subject. ${ }^{4}$ Morris et $a l^{5}$ suggested that cereal fibre intake was a more important protective factor against coronary heart disease than either the quantity or type of dietary fat, and also reaffirmed that high blood pressure predisposes people to cardiovascular diseases. A diet rich in fats will increase blood pressure in rabbits, ${ }^{6}{ }^{7}$ and dietary fibre partially protects rabbits against the hypertensive effects of fat-enriched diets. ${ }^{8}{ }^{9}$ Since Western man consumes a diet rich in fats it was of interest to assess the effects of dietary fibre intake on the arterial blood pressure of volunteers.

Experiments were performed on 42 volunteers who increased or decreased their intake of dietary fibre either by dietary counselling or by the consumption of special foods.

School of Biochemical and Physiological Sciences, University of Southampton, Southampton SO9 $37 \mathrm{U}$

ANGELA WRIGHT, final-year medical student

P G BURSTYN, PHD, lecturer in physiology

$M \mathrm{~J}$ GIBNEY, PHD, lecturer in nutrition

\section{Subjects and methods}

Volunteers were selected from the staff and students of the university (age range 18-60). An additional small group of volunteers were selected from hypertensive patients of a nearby health centre. Blood pressures were measured three times weekly in a quiet room at the university after a 10-minute rest or at the volunteer's home. Most of the values were recorded with a Hawkesley random zero sphygmomanometer to reduce observer bias. The hypertensive patients had their blood pressures measured only twice weekly with a standard Accoson sphygmomanometer. On each occasion three measurements were made in four to five minutes and the mean value recorded. The subjects were asked to clench their fist several times between each inflation of the cuff to prevent pooled blood from affecting the measurement. The fifth sound was used for diastolic pressures.

All the non-hypertensive volunteers performed a dietary survey weighing all food eaten during three days. Diet scales recording weights up to $500 \mathrm{~g}$ to the nearest $10 \mathrm{~g}$ were provided. Diet surveys were conducted once during the control period and during each fourweek experimental period. The composition of the diets was calculated from food tables, ${ }^{10}$ and subjects whose fibre intake was higher than the overall mean were classified as "high-fibre" subjects, whereas the remainder were classified as "low-fibre" subjects. The classification on the basis of the surveys agreed with a preliminary classification based on a questionnaire filled in by all participants before the experiment. Most high-fibre subjects consumed whole-meal bread and ate little white bread.

\section{EXPERIMENT 1}

Group A: 17 subjects whose usual diet was relatively low in fibre continued this diet for a three-week control period. They then increased their intake of dietary fibre for a single four-week experimental period on the basis of advice given them. Subjects were asked to substitute high-fibre foods for those normally consumed and were given a list of suggested substitutions-for example, whole-meal bread for white bread.

Group B: 14 subjects whose usual diet was relatively low in fibre continued this diet for a two-week control period. They were then given specially baked whole-meal bread with $10 \%$ added bran ad libitum to replace all of their whole-meal bread and asked to eat $5 \mathbf{g}$ of bran daily for two four-week periods.

Group C: 11 subjects whose usual diet was high in fibre continued this diet for a two-week control period. They were then given white bread ad libitum to replace all of their whole-meal bread and asked to refrain from eating high-fibre breakfast cereals for two four-week periods.

Both groups $\mathrm{B}$ and $\mathrm{C}$ were given lard and butter ad libitum during the first four-week experimental period. This saturated-fat regimen was what most of the subjects had been consuming before the experiment. During the second four-week period they were given corn oil and polyunsaturated margarine to replace the lard and butter.

\section{EXPERIMENT 2}

Twelve hypertensive patients who all had a typical western European diet-that is, one relatively low in fibre, continued with this diet for a two-week control period. They were then given specially baked whole-meal bread with $10 \%$ added bran ad libitum to replace all of their white bread and asked to consume $5 \mathrm{~g}$ of bran daily with their food for a six-week experimental period.

\section{SURVEY}

Fifty-two non-hypertensive subjects carried out a three-day dietary survey and had their blood pressures measured on a single occasion. They were then classified into a high-fibre group of 34 and a low-fibre 
group of 18. This classification was based on the results of the surveys also made on the 42 subjects participating in experiment 1 . The control blood pressures of the 42 subjects in experiment 1 were assessed in combination with the blood pressures of these 52 people to give a high-fibre group of 45 and a low-fibre group of 49. Fasting blood samples were taken from each volunteer during the control period and during each experimental period. These were allowed to clot and determinations of total serum cholesterol concentration, high density lipoprotein (HDL) cholesterol concentration, and triglyceride concentrations were performed using a Technicon autoanalyser. HDL was separated using a heparin-manganese solution. ${ }^{11}$ Both serum and the separated HDL were analysed for cholesterol ${ }^{12}$ and triglyceride concentrations. ${ }^{13}$

\section{Results}

\section{EXPERIMENT 1}

Group A (17 subjects) showed a mean decrease in systolic blood pressure of $3.2 \%$ and a mean decrease in diastolic blood pressure of $4.7 \%$ compared with control values after increasing their fibre intake. Their total dietary fibre increased by $47 \%$ and their intake of cereal fibre by $94 \%$ (table I). Group B (14 subjects) showed a mean decrease in systolic pressure of $1.5 \%$ and a mean decrease in diastolic pressure of $3.4 \%$. Their total dietary fibre increased by $126 \%$ and their intake of cereal fibre by $197 \%$ (table I). Group C (11 subjects) showed a mean increase in systolic pressure of $6.8 \%$ and a mean increase in diastolic pressure of $3.8 \%$. Their total dietary fibre decreased by $55 \%$ and their intake of cereal fibre by $62 \%$ on average (table I). Groups B and C changed their fat intake from ad libitum lard and butter to ad libitum corn oil and polyunsaturated margarine. Subjects in group C showed a mean decrease in systolic pressure of $4.3 \%$ and a mean decrease in diastolic pressure of $2.6 \%$. Subjects in group B showed a mean decrease in systolic pressure of $1.4 \%$ and

TABLE I-Experiment 1. Changes in blood pressure and fibre intake in three groups of subjects changing from high-fibre to low-fibre diets or vice versa. Figures are means \pm standard error

\begin{tabular}{|c|c|c|c|c|c|}
\hline & \multicolumn{2}{|c|}{$\begin{array}{l}\text { Blood pressure } \\
(\mathrm{mm} \mathrm{Hg})\end{array}$} & \multicolumn{2}{|c|}{$\begin{array}{l}\text { Dietary fibre } \\
(\mathrm{g} / \mathrm{MJ})\end{array}$} & \multirow{2}{*}{$\begin{array}{l}\text { Energy } \\
\text { intake } \\
(M J)\end{array}$} \\
\hline & Systolic & Diastolic & Total & Cereal & \\
\hline \multicolumn{6}{|c|}{ Group $A(n=17)$} \\
\hline \multirow{2}{*}{$\begin{array}{l}\text { diet } \\
\text { Significance } \\
\text { High-fibre experi- } \\
\text { mental diet }\end{array}$} & $\begin{array}{l}121 \cdot 2 \pm 1 \cdot 6 \\
P<0 \cdot 01\end{array}$ & $\begin{array}{l}78 \cdot 5 \pm 1 \cdot 7 \\
P<0 \cdot 001\end{array}$ & $\begin{array}{l}2 \cdot 36 \pm 0 \cdot 15 \\
P<0 \cdot 001\end{array}$ & $\begin{array}{l}1 \cdot 06 \pm 0 \cdot 16 \\
P<0 \cdot 001\end{array}$ & $\begin{array}{c}6 \cdot 86 \pm 0.40 \\
\text { NS }\end{array}$ \\
\hline & $117 \cdot 3 \pm 1 \cdot 7$ & $74 \cdot 8 \pm 1 \cdot 3$ & $3 \cdot 47 \pm 0 \cdot 12$ & $2 \cdot 06 \pm 0.19$ & $7.06 \pm 0.59$ \\
\hline \multicolumn{6}{|c|}{ Group $B(n=14)$} \\
\hline \multirow{2}{*}{$\begin{array}{l}\text { diet } \\
\text { Significance } \\
\text { High-fibre experi- } \\
\text { mental diet }\end{array}$} & $\begin{array}{l}119.9 \pm 1.6 \\
0.1>\mathrm{P}>0.05\end{array}$ & $\begin{array}{l}79.5 \pm 1.4 \\
P<0.01\end{array}$ & $\begin{array}{l}1 \cdot 61 \pm 0 \cdot 12 \\
P<0 \cdot 001\end{array}$ & $\begin{array}{l}0.93 \pm 0.04 \\
P<0.001\end{array}$ & $\begin{array}{c}7 \cdot 33 \pm 0.57 \\
\mathrm{NS}\end{array}$ \\
\hline & $118 \cdot 1 \pm 1 \cdot 5$ & $76 \cdot 8 \pm 1 \cdot 4$ & $3.63 \pm 0.43$ & $2 \cdot 76 \pm 0.32$ & $7.87 \pm 0.33$ \\
\hline \multirow{3}{*}{$\begin{array}{l}\text { High-fibre control } \\
\text { diet } \\
\text { Significance } \\
\text { Low-fibre experi- } \\
\text { mental diet }\end{array}$} & & Group $C(n=$ & 11) & & \\
\hline & $\begin{array}{l}113 \cdot 8 \pm 2 \cdot 6 \\
\mathrm{P}<0 \cdot 02\end{array}$ & $\begin{array}{c}74 \cdot 2 \pm 1 \cdot 6 \\
0.1>\mathrm{P}>0.05\end{array}$ & $\begin{array}{l}3.93 \pm 0.37 \\
P<0.001\end{array}$ & $\begin{array}{l}1 \cdot 99 \pm 0 \cdot 16 \\
P<0 \cdot 001\end{array}$ & $\begin{array}{c}7 \cdot 84 \pm 0 \cdot 48 \\
\text { NS }\end{array}$ \\
\hline & $121 \cdot 5 \pm 1 \cdot 4$ & $77 \cdot 0 \pm 1 \cdot 1$ & $1 \cdot 78 \pm 0 \cdot 21$ & $0.77 \pm 0.06$ & $8.29 \pm 0.62$ \\
\hline
\end{tabular}

Significance calculated by paired $t$ test.

NS = Not significant.

Conversion: $4 \cdot 2 \mathrm{MJ} \approx 1000 \mathrm{kcal}$.

TABLE II-Experiment 1. Changes in blood pressure and total fat intake in two groups of subjects (group $B$, experimental high-fibre diet, $n=14 ;$ group $C$, experimental low-fibre diet, $n=11$ ) changing part of their fat intake from saturated to polyunsaturated fats. Figures are means \pm standard error

\begin{tabular}{|c|c|c|c|c|c|}
\hline & & \multicolumn{2}{|c|}{$\begin{array}{l}\text { Blood pressure } \\
(\mathrm{mm} \mathrm{Hg})\end{array}$} & \multirow[t]{2}{*}{$\begin{array}{c}\text { Fat intake } \\
\text { (\% total energy) }\end{array}$} & \multirow{2}{*}{$\begin{array}{l}\text { Energy } \\
\text { intake } \\
(\mathrm{MJ})\end{array}$} \\
\hline & & Systolic & Diastolic & & \\
\hline \multicolumn{6}{|c|}{ Group B } \\
\hline $\begin{array}{l}\text { Saturated fat } \\
\text { Significance } \\
\text { Unsaturated fat } \ldots\end{array}$ & $\begin{array}{l}. \\
\because \\
.\end{array}$ & $\begin{array}{c}118 \cdot 1 \pm 1 \cdot 8 \\
\text { NS } \\
116 \cdot 4 \pm 1 \cdot 9\end{array}$ & $\begin{array}{l}76 \cdot 8 \pm 1 \cdot 4 \\
\mathrm{NS} \\
75 \cdot 0 \pm 1 \cdot 5\end{array}$ & $\begin{array}{l}37 \cdot 0 \pm 1 \cdot 5 \\
\mathrm{NS} \\
40 \cdot 0 \pm 1 \cdot 6\end{array}$ & $\begin{array}{l}7.87 \pm 0.33 \\
\mathrm{NS} \\
8 \cdot 26 \pm 0.60\end{array}$ \\
\hline \multicolumn{6}{|c|}{ Group C } \\
\hline $\begin{array}{l}\text { Saturated fat } \ldots \\
\text { Significance } \\
\text { Unsaturated fat .. }\end{array}$ & $\begin{array}{l}. \\
\cdots\end{array}$ & $\begin{array}{l}121 \cdot 5 \pm 1 \cdot 4 \\
\mathrm{P}<0.01 \\
116 \cdot 3 \pm 2 \cdot 1\end{array}$ & $\begin{array}{l}77 \cdot 0 \pm 1 \cdot 1 \\
0 \cdot 1>\mathbf{P}>0.05 \\
75 \cdot 0 \pm 1 \cdot 6\end{array}$ & $5 \begin{array}{c}36 \cdot 7 \pm 2 \cdot 2 \\
\mathrm{NS} \\
34 \cdot 0 \pm 1 \cdot 3\end{array}$ & $\begin{array}{c}8 \cdot 29 \pm 0.62 \\
\mathrm{NS} \\
8.33 \pm 0.37\end{array}$ \\
\hline
\end{tabular}

Significance calculated by paired $t$ test. NS $=$ Not significant.

Co.tversion: $4 \cdot 2 \mathrm{MJ} \approx 1000 \mathrm{kcal}$. a mean decrease in diastolic pressure of $2.3 \%$, neither being statistically significant (table II). The mean proportion of polyunsaturated fat in the diets of both groups $\mathrm{B}$ and $\mathrm{C}$ increased from $7.8 \% \pm$ $1 \cdot 1 \%$ to $21 \cdot 1 \% \pm 2 \cdot 7 \%$ while their total fat intake was unchanged.

In these experiments the changes in total and HDL cholesterol concentrations and triglyceride concentrations were small and unrelated to the changes in blood pressure. There were no consistent weight changes in any of the groups for any of the dietary regimens. The proportion of energy obtained from fats, proteins, and carbohydrates was similar in all of the groups and was largely unaffected by the dietary changes.

\section{EXPERIMENT 2}

The 12 hypertensive patients, who roughly doubled their fibre intake, showed a mean decrease in systolic pressure of $1.7 \%$ and a mean decrease in diastolic pressure of $3.9 \%$, neither change being statistically significant. The individual blood pressure values in this group varied substantially.

\section{SURVEY}

The mean systoiic pressure of the high-fibre group (45 subjects) was $6.1 \%$ lower and the diastolic pressure $4.4 \%$ lower than that of the low-fibre group (49 subjects). The high-fibre group consumed twice as much dietary fibre as the low-fibre group. No estimate of the difference in cereal fibre intake between these two groups is available (table III). The high-fibre group had mean total serum cholesterol concentrations that were $16 \%$ lower and $25 \%$ more cholesterol in HDL than the low-fibre group. There was no significant difference in mean total serum triglyceride concentrations between the groups. There was no significant difference in age, weight, or sex distribution between the groups.

TABLE III-Difference in blood pressure, total fibre intake, and serum lipid concentrations in 94 subjects divided into a group habitually eating a high-fibre diet and a group habitually eating a low-fibre diet. Figures are means \pm standard error

\begin{tabular}{|c|c|c|c|c|c|}
\hline & \multirow{2}{*}{\multicolumn{2}{|c|}{$\begin{array}{l}\text { Blood pressure } \\
\text { (mm Hg) }\end{array}$}} & \multirow{3}{*}{$\begin{array}{l}\text { Total } \\
\text { dietary } \\
\text { fibre } \\
(\mathrm{g} / \mathrm{MJ})\end{array}$} & \multicolumn{2}{|c|}{ Serum cholesterol } \\
\hline & & & & \multirow{2}{*}{$\underset{(\mathrm{mmol} / \mathrm{l})}{\text { Total }}$} & \multirow{2}{*}{$\begin{array}{l}\text { HDL: } \\
\text { Total }\end{array}$} \\
\hline & Systolic & Diastolic & & & \\
\hline $\begin{array}{l}\text { Low fibre }(n=49) \\
\text { Significance } \\
\text { High fibre }(n=45)\end{array}$ & $\begin{array}{l}123 \cdot 3 \pm 1 \cdot 3 \\
\mathrm{P}<0 \cdot 001 \\
116 \cdot 2 \pm 1 \cdot 5\end{array}$ & $\begin{array}{l}78 \cdot 5 \pm 0 \cdot 8 \\
P<0 \cdot 02 \\
75 \cdot 2 \pm 1 \cdot 0\end{array}$ & $\begin{array}{l}1 \cdot 64 \pm 0 \cdot 12 \\
\mathrm{P}<0.001 \\
3 \cdot 44 \pm 0 \cdot 21\end{array}$ & $\begin{array}{l}5 \cdot 5 \pm 0 \cdot 1 \\
\mathrm{P}<0 \cdot 02 \\
4 \cdot 8 \pm 0 \cdot 2\end{array}$ & $\begin{array}{l}0.3 \pm 0.02 \\
P<0.01 \\
0.4 \pm 0.02\end{array}$ \\
\hline
\end{tabular}

Significance calculated by Student's $t$ test. HDL $=$ High-density lipoprotine. Conversion: SI to traditional units-Cholesterol: $1 \mathrm{mmol} / 1 \approx 38.6 \mathrm{mg}$ / $100 \mathrm{ml}$.

\section{Discussion}

People habitually consuming a diet rich in fibre may have lower blood pressures than people eating a low-fibre diet. The high-fibre groups reported here had lower mean total serum cholesterol concentrations, and more of this cholesterol was in the HDL fraction. Increasing the fibre intake of subjects on a low-fibre diet lowered their mean blood pressure, and decreasing the fibre intake of subjects on a high-fibre diet increased their mean blood pressure, the magnitude of these changes being less than the original mean difference in blood pressure between the groups. Larger changes might have occurred had the experiments continued. These results agree with recent reports showing that rabbits on fat-enriched diets can be made less prone to hypertension by the addition of fibre to such diets. ${ }^{89}$

Our failure to observe statistically significant changes in the blood pressures of the hypertensive patients may have been due to the instability of their blood pressures. These patients were being treated with various antihypertensive drugs, and fluctuations in their drug intake or in the rate of absorption of the drugs may have been a factor causing this instability. Nevertheless, Dodson and Humphrey found that special diets 
with a high fibre content lowered blood pressures in hypertensive patients. ${ }^{14}$ Changing part of the dietary fat from saturated to polyunsaturated lowered the blood pressure by a statistically significant amount only in the group of subjects eating the lowfibre experimental diets, though subjects on high-fibre experimental diets also showed a drop in blood pressure. These results agree with those of Iacono et $a l^{15}$ which showed that partial replacement of saturated dietary fats with polyunsaturated fats reduced the blood pressures of volunteers. The reductions they reported were greater than those we achieved, but they effected a $40^{\circ}$ reduction in total fat intake as well as altering the type of fat consumed. In rabbits polyunsaturated fats tend to cause less hypertension than saturated fats. ${ }^{6} 79$ Although subjects eating a high-fibre diet were found to have lower mean total serum cholesterol concentrations than those eating a lowfibre diet, we confirm the observations of Truswell who reported that changes in dietary fibre intake have little effect on serum cholesterol concentration over a relatively short time. ${ }^{16}$

Populations of vegetarians may have lower blood pressures than comparable populations of non-vegetarians. ${ }^{17-19}$ Furthermore, Donaldson ${ }^{20}$ showed that the blood pressures of five vegetarians increased by $10 \%$ when they were given a meat diet for about two weeks. The vegetarian diet usually contains less fat than the non-vegetarian diet and a larger proportion is polyunsaturated. Since almost all plant foods contain dietary fibre, the vegetarian's fibre intake is higher than that of the non-vegetarian. ${ }^{21}$ The results of Iacono et $a l^{15}$ and those presented here suggest that much of the observed blood pressure differences between vegetarians and non-vegetarians may be caused by differences in the type and quantity of dietary fibre and fats. The role of protein is not yet clear, but preliminary results $^{22}$ suggest that replacing part of the normal dietary protein with soya protein has little effect on blood pressure in man.

The mechanism of the blood-pressure lowering effect of dietary fibre is not known. Recent studies have shown that in rabbits fed fat-enriched diets a negative correlation exists between plasma triglyceride concentrations and blood pressure, which was not seen with fat-enriched diets that also contained large amounts of fibre. ${ }^{23}$ This was not found in the present study. In man, high serum cholesterol concentrations may accompany high blood pressures. ${ }^{17}$ Burstyn and Husbands ${ }^{23}$ also found this to be true but concluded that, though serum cholesterol concentrations may increase as a result of consuming a fat-enriched diet, the rise in serum cholesterol concentration did not seem to be related to the rise in blood pressure. Whereas dietary fats inhibit gastrointestinal motility, fibre increases it by increasing the bulk of the intestinal contents, stretching the intestine and stimulating the smooth muscle, and possibly also by diluting the fats in the intestinal chyle, thereby reducing their stimulation of intestinal receptors. Thus the secretion of gastrointestinal hormones may be substantially altered by the presence of dietary fibre. Alternatively the rate of absorption of carbohydrates from the intestinal lumen may be substantially decreased by dietary fibre. ${ }^{24}$ The presence of fibre in the diet, by changing the pattern of absorption of nutrients, reduces insulin production, ${ }^{25}$ and may also be expected to change the secretion of glucagon and glucocorticoids, which in turn may affect the circulatory system.

Even mild hypertension is associated with an increased risk of cardiovascular disease. ${ }^{26}$ The lower mean blood pressure of people taking a high-fibre diet may be one reason why Morris et $a l^{5}$ found a lower incidence of coronary heart disease in such people, and why groups of vegetarians tend to have less coronary heart disease than comparable groups of non-vegetarians. ${ }^{27} 28$

We thank Dr Cynthia Taylor (Aldermoor Health Centre) for helping us contact a group of hypertensive patients; Dr M Gore for help with the lipid assays; Professor $T$ G Taylor for advice and criticism; and particularly Mr G Cotton, baker and confectioner, for producing a light and delicious bran-enriched whole-meal bread.

Correspondence should be addressed to P G Burstyn.

\section{References}

1 Trowell, H C, in The Present State of Knowledge 6. London, Norgine, 1976.

2 Trowell, H C, in The Present State of Knowledge 7. London, Norgine, 1976.

${ }^{3}$ Select Committee on Nutrition and Human Needs, Dietary Goals for the United States. Washington, United States Senate, 1977.

4 Oliver, M F, in Diet of Man: Needs and Wants, ed J Yudkin. London, Applied Science Publishers, 1978.

${ }^{5}$ Morris, J N, Marr, J W, and Clayton, D G, British Medical Fournal, 1977, 2, 1301

${ }^{6}$ Burstyn, P G, and Firth, W R, Cardiovascular Research, 1975, 9, 807.

${ }^{7}$ Burstyn, P G, Horrobin, D F, and Muiruri, K M, British fournal of Experimental Pathology, 1972, 53, 258.

${ }^{8}$ Gardey, T, Burstyn, P G, and Taylor, T G, Proceedings of the Nutrition Society, 1978, 37, 97A.

${ }^{9}$ Kennedy, M, Burstyn, P G, and Husbands, D R, Proceedings of the Nutrition Society, 1978, 37, 98A.

10 Paul, A A, and Southgate, D A T, The Composition of Foods, 4th edn. London, HMSO, 1978.

11 Burstein, M, Scholnich, H R, and Morfin, R, Fournal of Lipid Research, 1970, 11, 583.

12 Technicon Clinical Method 16A.

${ }^{13}$ Kessler, G, and Lederer, H, in Automation in Analytical Chemistry, p 341. New York, Mediad, 1965.

14 Dodson, P, and Humphrey, D, in Western Diseases: Their Emergence and Prevention, ed H Trowell and D Burkitt. London, Edward Arnold. In press.

15 Iacono, J M, et al, Preventive Medicine, 1975, 4, 426.

16 Truswell, A S, American fournal of Clinical Nutrition, 1978, 31, 977.

17 Malhotra, S L, American fournal of Clinical Nutrition, 1970, 23, 1353.

18 Sacks, F M, Rosner, B, and Kass, E H, American fournal of Epidemiology, 1974, 100, 390.

${ }^{19}$ Armstrong, B, van Merwyk, A J, and Coates, H, American fournal of Epidemiology, 1977, 105, 444

${ }^{20}$ Donaldson, A N, California and Western Medicine, 1926, 24, 328.

21 Gear, J S S, et al, Lancet, 1979, 1, 511.

${ }^{22}$ Burstyn, $P$ G, and Gibney, $M$ J, unpublished results.

${ }^{23}$ Burstyn, P G, and Husbands, D R, Cardiovascular Research. In press.

${ }^{24}$ Wolever, T M S, et al, Proceedings of the Nutrition Society, 1978, 37, 47A.

${ }^{25}$ Haber, G B, et al, Lancet, 1977, 2, 679.

${ }^{26} \mathrm{Kannel,W}$ B, et al, Annals of Internal Medicine, 1964, 61, 888.

${ }^{27}$ Groen, J J, et al, American fournal of Clinical Nutrition, 1962, 10, 456.

${ }^{28}$ Hardinge, M G, and Stare, F J, fournal of Clinical Nutrition, 1954, 2, 83.

(Accepted 2 October 1979)

ONE HUNDRED YEARS AGO Dr George M Beard (New York Medical Record, March 15th, 1879), gives the results of an extended study of writers' cramp observed in one hundred and twenty cases. 1. What is called writers' cramp is but one of a large number of symptoms of the disease, and no two cases are precisely alike. Among these are fatigue, exhaustion, dull aching pain, nervous, irritable feeling, general nervousness, trembling, unsteadiness, cramp, spasm, jumping, twitching, rigidity, contraction of muscles, etc. 2. In other forms of professional cramp, as that of telegraphers, musicians, sewing women, painters, artists, dancers, hammer-palsy, and so forth, the cramp is but one of a number of symptoms, and by no means the most important one. As in the writers' cramp, there is frequently no cramp at all from the beginning to the end of the disease. 3. This disease is primarily a peripheral and local disease of the nerves and muscles; secondarily and rarely it becomes central and general, or it may result from various central lesions; and it may affect any point between the extreme periphery and the centre. 4 . This disease occurs mostly in those who are strong, frequently of very strong constitutions, and is quite rare in the nervous and delicate; and when it does occur in those who are nervous, is more easily relieved and cured than when it occurs in the strong. 5. This disease is far less likely to occur in those who do original work, as authors, journalists, composers, than in those who do routine work, as clerks, book-keepers, copyists, agents, and so forth. 6. This disease, like all nervous diseases in this country, diminishes in frequency as we go south. 7. Writers' cramp is no longer an incurable disease. 8 . The treatment of writers' cramp and affections allied to it consists- $a$. In the use of electricity locally applied; $b$. Hypodermic injections of atropia, strychnia, duboisia, Fowler's solution, and other tonics, narcotics, and sedatives; $c$. The internal use of Calabar bean, ergotine, iodoform, and in some cases of nerve-food, as oil and fats; $d$. Massage; $e$. The alternate use of hot and cold Indiarubber bags; $f$. The use of the actual cautery and very small blisters to the upper portion of the spine, or along the course of the affected nerves and muscles. (British Medical fournal, 1879.) 